Article

\title{
Vertical Guided Bone Augmentation Using Titanium Mesh Domes Coated with Natural Latex Extracted from Hevea brasiliensis
}

\author{
Diego K. Pons ${ }^{1,2} \mathbb{D}^{D}$, Rachel G. Eleuterio ${ }^{1,3}{ }^{\text {, Fábio F. G. Paiva }}{ }^{4} \mathbb{D}^{\mathbb{D}}$, Leandro A. Holgado ${ }^{1}$, \\ Leonardo Marques ${ }^{1}\left(\mathbb{D}\right.$, Alberto Consolaro ${ }^{5}$, Carlos F. O. Graeff ${ }^{6}\left(\mathbb{D}\right.$, Oswaldo Baffa ${ }^{7}(\mathbb{D})$ and \\ Angela Kinoshita $1,4, *$ (D) \\ 1 PRPPG, Universidade do Sagrado Coração-USC, Bauru-SP 17011-160, Brazil \\ diegoponsrs@gmail.com (D.K.P.); rachelgomeseleuterio@gmail.com (R.G.E.); \\ leandroah@terra.com.br (L.A.H.); marquesodontologia@hotmail.com (L.M.) \\ 2 Pós Graduação, Faculdade Especializada na Área da Saúde do Rio Grande do Sul-FASURGS, \\ Passo Fundo-RS 99025-270, Brazil \\ 3 Departamento de Anatomia e Implantodontia, Universidade de Marília-UNIMAR, \\ Marilia-SP 17525-902, Brazil \\ 4 PGMADRE, Universidade do Oeste Paulista-UNOESTE, Presidente Prudente-SP 19067-175, Brazil; \\ fabio.vha@hotmail.com \\ 5 FOB, Universidade de São Paulo-USP, Bauru-SP 17012-901, Brazil; consolaro@uol.com.br \\ 6 FCT, Universidade Estadual Paulista-UNESP, Bauru-SP 17033-360, Brazil; carlos.graeff@unesp.br \\ 7 Departamento de Física, Universidade de São Paulo-FFCLRP-USP, Riberão Preto-SP 14040-900, Brazil; \\ baffa@usp.br \\ * Correspondence: angelamitie@gmail.com; Tel.: +55-14-99721-3063
}

Received: 25 May 2020; Accepted: 19 June 2020; Published: 25 June 2020

\begin{abstract}
The subject of this work is the evaluation of the use of titanium mesh domes coated with latex extracted from Hevea brasiliensis to promote vertical guided bone augmentation (GBA), above the normal limits of the skeleton. Twenty-four New Zealand rabbits were used, in which a circular groove of eight millimeters in diameter and nine holes in the internal region reaching the medulla were made with a trephine drill, in the calvaria. The dome, four millimeters in height, was fixed above this defect. The animals were divided into four groups $(N=6)$. The first (control) received a titanium dome not covered by the periosteum, and the second received a titanium dome that was covered by the periosteum. For the third, a dome with a latex coating was used and was not covered by the periosteum, and for the fourth, a titanium dome with a latex coating was used and was covered by the periosteum. After 90 days, the animals were euthanized. Computerized tomography imaging demonstrated that vertical bone augmentation was achieved in the groups with titanium domes coated with latex. Microscopic evaluation showed that there were no differences between the control group and Group 2, or between Groups 3 and 4 . The other comparisons showed statistically significant differences $(p<0.05$, ANOVA-Tukey).
\end{abstract}

Keywords: bone augmentation; titanium; latex

\section{Introduction}

Bones develop through a process of ossification or osteogenesis and are constantly remodeling. Some bone structures are dependent on the tissues attached to them, such as the jaws, where the alveolar bone is dependent on the periodontal ligament. Throughout life, several situations can lead to important changes in bone anatomy and to subsequent dysfunction that impacts the quality of 
life and, sometimes, the individual's longevity. Several bone defects located in the jaws, considered challenging in terms of rehabilitation, are often the result of dental agenesis, periodontal diseases, long-standing bone remodeling due to the early loss of dental elements, traumatic dental extractions, facial trauma, the removal of intraosseous cystic lesions and surgeries for tumor extraction, among other reasons [1]. When a trauma occurs with the loss of bone structure, the defect is usually filled, for the most part, with fibrous connective tissue due to the proliferative capacity of this tissue, which prevents the maintenance of the anatomy, promoting the formation of bone defects. In dentistry, several reconstructive procedures have been created and improved, using bioengineering methods adopted from the concepts of regenerative medicine, in order to minimize the sequelae resulting from tooth and bone loss. Surgical techniques for alveolar bone augmentation have obtained good results associating soft and hard tissues during bone reconstructions of the jaws, being associated with the use of dental implants, assisting the restoration of oral and maxillofacial functions [2]. Guided bone regeneration (GBR) is used-especially in oral and maxillofacial surgery, periodontology and implant dentistry-to reconstruct the bone defect, restoring its original anatomical and functional structures [3]. The increase in thickness or the horizontal dimension is more predictable when compared to the augmentation in height or the vertical dimension. Roccuzzo et al. [4] report that increasing bone vertically is still a major challenge, due to the fact that it is not surrounded by bony walls, resulting in the insufficient recruitment of osteogenic cells. Another difficulty is the covering of the enlarged site, due to the insufficient amount of soft tissue around it, sometimes causing an exposure of the surgical bed, leading to serious complications such as infection after exposure of the membrane. Thus, some treatments involve antimicrobials associated with biomaterials. Zhang et al. [5] investigated the biomaterial Bio-Oss associated with doxycycline for guided bone augmentation (GBA). They report an inhibitory effect on inflammation, osteoclastogenesis and a stimulation of bone formation. Recombinant human bone morphogenetic protein 2 (rhBMP-2) is an osteoinductor often used for bone regeneration in oral and maxillofacial surgery. Mish et al. [6] showed that rhBMP-2 and a particulate mineralized bone allograft protected by a titanium mesh produces a vertical bone increase, allowing the placement of dental implants. Similarly, Polo et al. associated rhBMP-2 with bone substitutes and were successful in GBA. The biomaterials BCP (biphasic calcium phosphate) and $\beta$-TCP (tricalcium phosphate) exhibited a synergistic effect with rhBMP-2, acting as suitable and viable carriers for vertical bone augmentation. Other authors have used stem cells to stimulate bone formation. Carrera-Arrabal et al. [7] used xenograft blocks fixed with titanium screws in the calvaria, after the decortication of the parietal bone, combining them with two types of mesenchymal stem cells derived from bone marrow and adipose tissue. They report that stem cells derived from bone marrow appear to have more potential for bone formation than stem cells derived from adipose tissue when used in combination with xenogenous blocks in vertical bone construction. Therefore, to achieve the desired results in GBA, it is possible to use scaffolds, biomaterials from different origins, cell therapies and cell growth factors. A combination of them is widely used in dentistry, due to the fact that they obtain better results in combination than when used alone, according to the principles of osteoconduction, osteoinduction and osteogenesis [2].

Different types of membranes have been studied to promote guided bone regeneration. The most recognized membrane used for GBR is made of polytetrafluoroethylene (PTFE) [8]. Resorbable materialssuch as collagen, polylactide acid (PLA), polylactic acid (PLA)/poly (glycolide-co-lactide) copolymer) (PLA/PLGA) [9] and silk fibers [10] —are an attractive alternative because they do not require a second surgery for their removal. However, a comparative study showed that the non-resorbable membranes are more effective, preventing the soft tissue from migrating into the area of the bone defect [8].

A biomaterial that has been studied due to its biological properties is the natural latex extracted from the Hevea brasiliensis tree. Mendonça et al. [11] demonstrated the capacity of latex to induce angiogenesis. Kerche-Silva et al. [12] demonstrated the antioxidative capacity of latex C-serum in addition to the absence of cytotoxicity. These characteristics are important in several situations involving tissue repair processes. Our previous study showed the use of latex film as an occlusive membrane in GBR procedures for healing critical bone defects, with positive results $[13,14]$. Studies have also 
shown the possibility of adding substances that could be useful in bone healing-such as proteins [15], antibiotics [16-20] and silver nanoparticles (AgNP) [21]—to the latex film, forming a system with an occlusive barrier and drug delivery function, simultaneously. Herculano et al. [15] studied the natural rubber latex (NRL) membranes as a protein delivery system using bovine serum albumin as a model. The BSA was incorporated in the latex solution, which was subsequently polymerized at different temperatures. As a result, it was observed that the polymerization temperature affects the protein release rate; a temperature of $27^{\circ} \mathrm{C}$ produces the release of $66 \%$ of its BSA content for up to 18 days. This result could be interesting when a treatment with long-term release of the drug is desired. Similarly, metronidazole, a drug used for periodontal disease, can be released gradually by the latex matrix. Drug release was observed for up to approximately $100 \mathrm{~h}$ in in vitro experiments [16]. More recently, Marques et al. [21] studied the performance of the natural latex matrix impregnated with AgNP in guided bone regeneration. The antimicrobial action of the biomaterial was verified, in addition to its biocompatibility. In in vivo tests on bone defects of critical size in the skull caps of rats, the new biomaterial showed satisfactory performance, accelerating the bone repair process.

Several studies have demonstrated the possibility of bone augmentation beyond the outer limits of the skeleton by GBR [22-24], contributing to solving a great problem in Implantology, that is, the insufficient bone volume at the implant site. The gold standard procedure adopted in this situation is the use of autografts. However, this procedure requires a donor site, in some cases obtained by a surgical procedure using prolonged general anesthesia, leading to a long period of hospitalization and morbidity $[25,26]$.

Thus, the subject of this work is the use of GBR to promote bone augmentation beyond the structure using natural latex in a dome shape. For this purpose, a domed-shaped structure made of titanium mesh and coated with natural latex was developed, and its ability to occlude defects and contribute to increasing bone volume was tested in an animal model. Additionally, the influence of periosteum was studied by covering, or not covering, the domes in the surgical procedure. Ninety days after surgery, the animals were euthanized, and the structures grown within the domes were assessed microscopically and by computerized tomography.

\section{Materials and Methods}

\subsection{Latex-Titanium Domes}

The titanium meshes (DePuy Synthes, Raynham, MA, USA) were domed-shaped (10 mm in diameter, $4 \mathrm{~mm}$ in height and $0.3 \mathrm{~mm}$ thick) and made using a metal cast. Some of them (twelve) were coated with centrifuged latex colloidal suspension (BDF Comércio de Produtos Agrícolas, São Paulo, Brazil). They were immersed in latex suspension for later natural polymerization, at room temperature. This procedure was repeated 3 times, in order to ensure that the entire mesh surface was covered by the polymer (Figure 1). After polymerization, the latex completely covered the mesh.

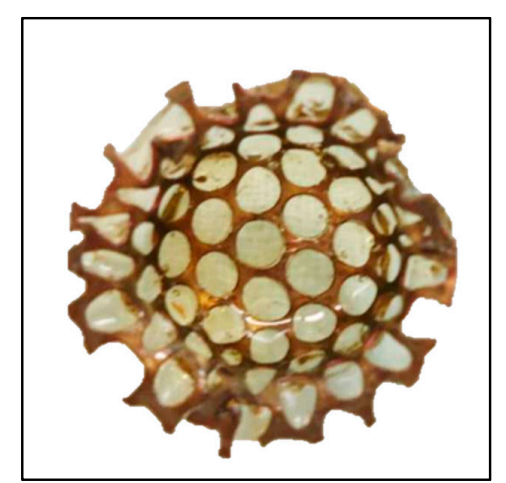

Figure 1. Titanium mesh dome shaped with a $10 \mathrm{~mm}$ diameter, coated with polymerized natural rubber latex. 
The domes were gamma sterilized-with a dose of $25 \mathrm{kGy}$ in a Gammacell Cobalt 60 Irradiator (Atomic Energy of Canada Limited, Ontario, Canada) in air at room temperature, with a dose rate of $0.634 \mathrm{kGy} / \mathrm{h}$-for use in the experiments. This procedure was used in several previous studies, and it did not affect the mechanical barrier capacity of the latex $[13,14,21]$.

\subsection{Surgical Procedure}

The present study was approved by the Ethical Committee from the Universidade do Sagrado Coração-USC (Bauru, São Paulo State, Brazil, protocol code 159/09) and was conducted according to recommendations set forth by the National Institute of Health (NIH, Bethesda, MD, USA) [27].

A total of 24 male New Zealand adult rabbits, aged approximately 180 days, weighing an average of $3.0 \mathrm{~kg}$ were used. The animals were kept in a standard cage in an experimental animal room and were fed ad libitum with a standard laboratory diet and water. Preoperatively, deep sedation was induced in the animals with xylazine chlorhydrate $(5 \mathrm{mg} / \mathrm{kg}$, Bayer, São Paulo, Brazil) and ketamine ( $35 \mathrm{mg} / \mathrm{kg}$, Vetbrands, Goiânia, Brazil). This procedure produces a sedative effect lasting 20-70 min, long enough for the surgical procedure to be performed. The dorsal part of the cranium was shaved and aseptically prepared for surgery. The local anesthetic mepivacaine $(2 \%)$ with epinephrine $(1: 100,000)$ was administered (Figure 2A); subsequently, a linear incision, $5 \mathrm{~cm}$ long, was made on the skin at the median sagittal line (Figure 2B). The musculature and the periosteum were reflected, exposing the parietal bone (Figure 2C). A trephine bur (Neodent ${ }^{\circledR}$, Curitiba, Brazil) with an $8 \mathrm{~mm}$ diameter was used to create the defect (Figure 2D).

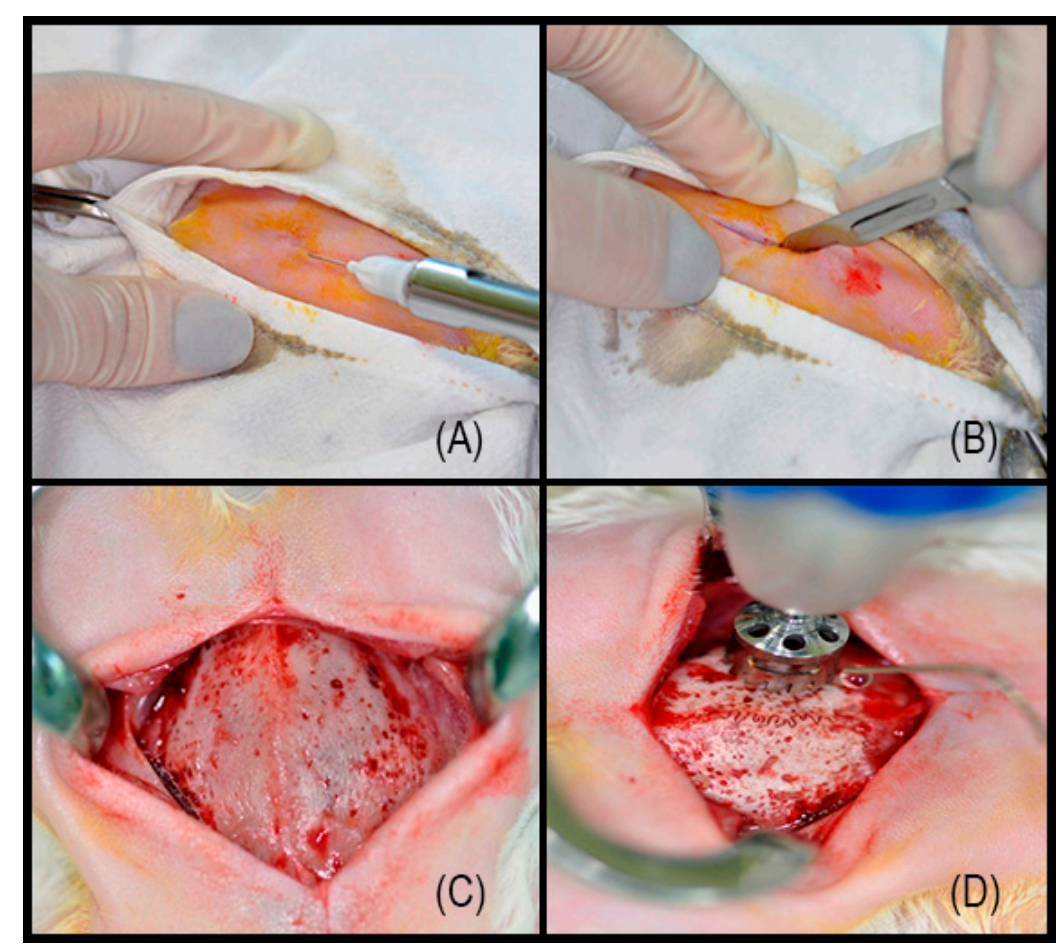

Figure 2. (A) Local anesthetic; (B) Linear incision, $5 \mathrm{~cm}$ long; (C) Parietal bone exposed; (D) Trephine bur with $8 \mathrm{~mm}$ diameter used to create the defect.

A bone defect in the first cortical layer, reaching the marrow, with an $8 \mathrm{~mm}$ diameter and 9 holes within it was surgically created in the skull, lateral to the midline suture (Figure 3A). The defect was created by means of a trephine (Neodent ${ }^{\circledR}$, Curitiba, Brazil) bur operating at low rotation under irrigation with sterile physiological solution $(0.9 \% \mathrm{NaCl})$ and a diamond burr (KG Sorensen 1016, São Paulo, Brazil). 


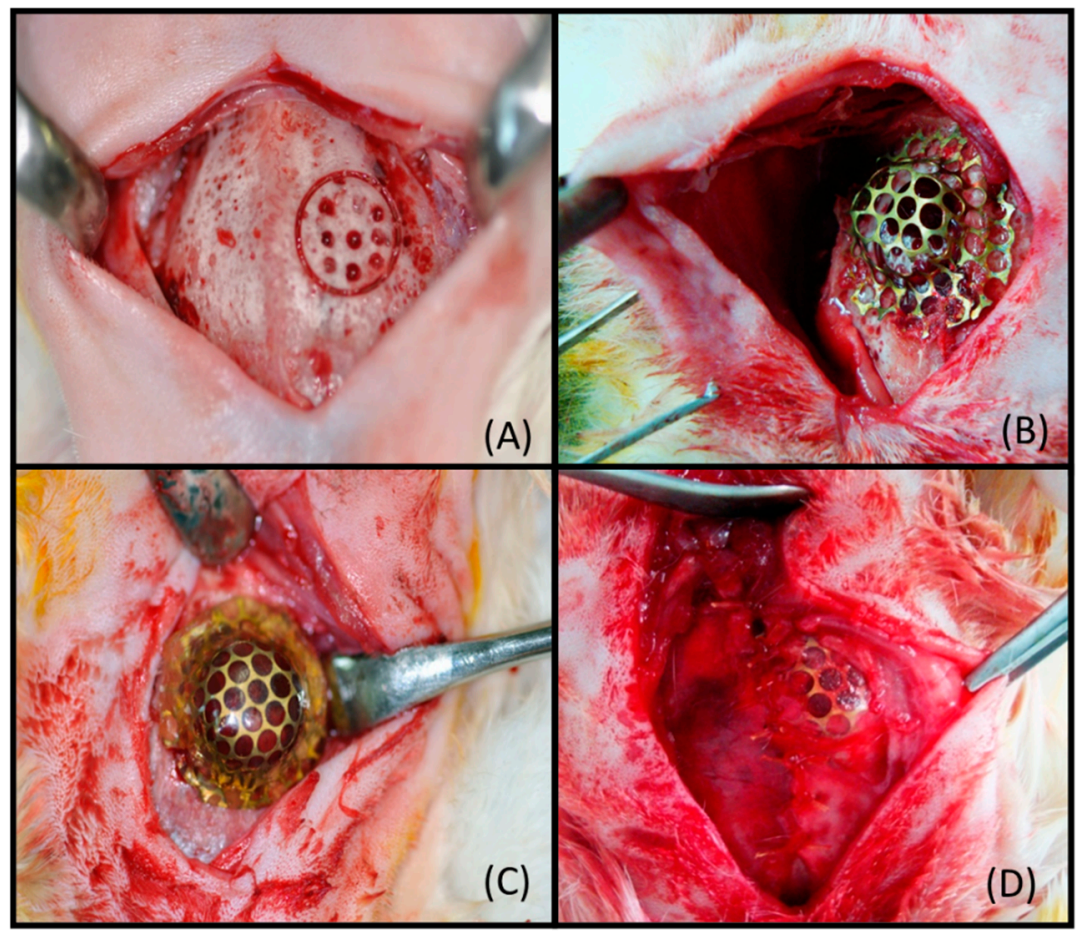

Figure 3. (A) Bone defect with $8 \mathrm{~mm}$ diameter and 9 perforations; (B) Titanium dome fixed above the defect; (C) Titanium dome coated by latex fixed above the defect; (D) Periosteum membrane sutured over the dome (Groups 2 and 4).

The domes (with and without latex coating) were fixed above the defect using Cyanoacrylate adhesive (Figure 3B,C). The animals were divided in 4 groups: Group 1, the control group $(N=6)$, received the defects treated with the titanium dome mesh, and this dome was not covered by periosteum; Group $2(N=6)$ received the defects treated with the titanium dome mesh, and this dome was covered by periosteum; Group 3 received the dome coated by latex, and this dome was not covered by periosteum; and Group $4(N=6)$ received the dome coated by latex, and this dome was covered by periosteum. (Figure 3D). Figure 3 shows the bone defect (Figure 3A) in the rabbit calvaria and the fixation of the dome (Figure 3B,C) during the surgical procedure. Animals from Groups 2 and 4 had the domes covered by the periosteum (Figure 3D).

The soft tissues and skin incisions were closed with 4-0 silk interrupted sutures. In the postoperative period, $0.1 \mathrm{~mL}$ of dipyrone $(500 \mathrm{mg} / \mathrm{mL})$ was injected intramuscularly and maintained at $8 / 8 \mathrm{~h}$ for 3 days for postoperative analgesia. After 90 days post-surgery, the animals were euthanized, and specimens containing the bone defects were collected.

\subsection{Computed Tomography Images}

After $48 \mathrm{~h}$ of formalin fixation, the dome was removed from samples from Groups 3 and 4. These specimens were subjected to tomographic imaging with the Philips Brilliance Big Bore equipment (Philips, Eindhoven, The Netherlands). Axial images were acquired with a $0.3 \mathrm{~mm}$ thick, $133 \mathrm{~mm}$ diameter reconstruction, a source-detector distance of $940 \mathrm{~mm}$, a source-sample distance of $535 \mathrm{~mm}$, a $115 \mathrm{~mm}$ height, a clockwisedirection of rotation, an $800 \mathrm{~s}$ exposure time, a tube current of $75 \mathrm{~mA}$, an exposure of $60 \mathrm{~mA}$, and a tension of $110 \mathrm{kV}$. The removal of the domes from Groups 1 (control) and 2 was not possible due to the high infiltration of soft tissue inside the domes, linking the internal and external regions. 


\subsection{Microscopic Analysis}

The bone samples were kept in phosphate buffered formalin (10\%, Merck, São Paulo, Brazil) for $48 \mathrm{~h}$ and decalcified using the ethylenediaminetetraacetic acid (EDTA) method.

The domes from Groups 3 and 4 were easily removed, after $48 \mathrm{~h}$ of fixation, differently from those from Groups 1 and 2, in which the titanium mesh was strongly surrounded by soft tissue. In these groups, the dome was removed after the decalcification step, with the careful clipping of the mesh at several points, for its removal.

Afterwards, the samples were processed for routine microscopy. Serial $6 \mu \mathrm{m}$ - thick sections were cut in the central region of the dome and stained with hematoxylin/eosin and Masson Trichromic stain. The specimens were analyzed with a Nikon H550L optical microscope (Nikon Instruments Inc. Melville, NY, USA).

\section{Results}

\subsection{Macroscopic Analysis}

The domes of the specimens from all the groups were in the same place in which they were implanted during surgery. Figure 4 shows photographs of samples collected. In the samples from Groups 1 (control) and, 2 there were large amounts of soft tissue surrounding the domes and through its perforations, occupying its inner area. A strong connection between the domes and the surrounding tissue was observed (Figure $4 \mathrm{~A}, \mathrm{C}$ ). In these groups, the domes were removed after cutting the titanium mesh that was highly interspersed with tissues. Figure 4B,D show the photographs taken after the domes were removed, showing the invasion of soft tissue in the internal region of the dome, which prevented the formation of bone tissue.

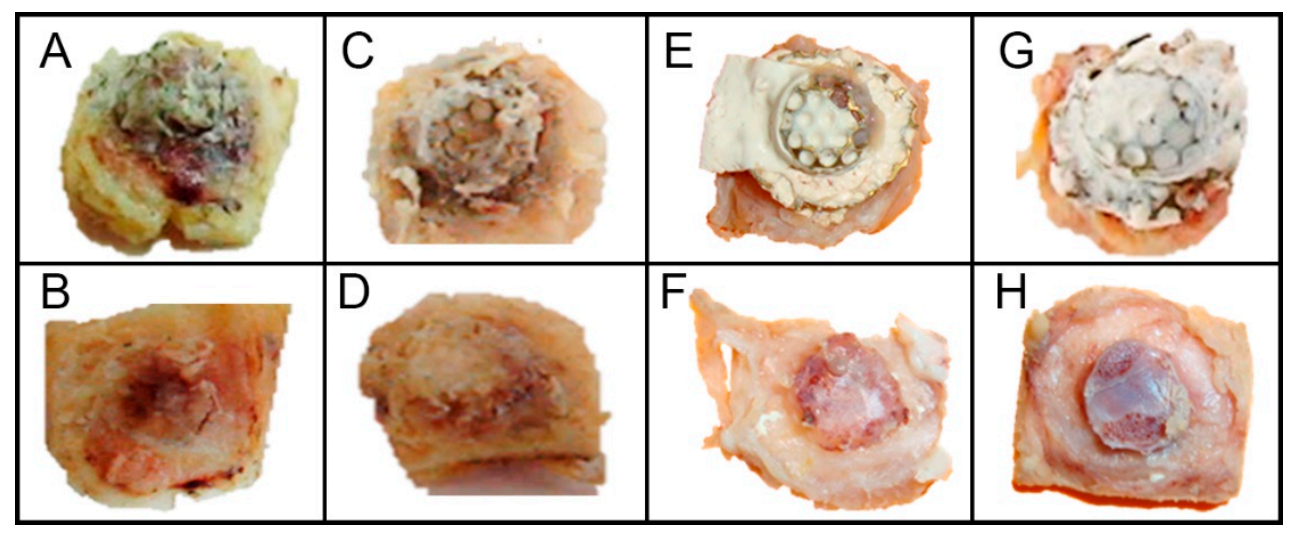

Figure 4. Photographs of the samples removed after 90 days of surgery. Photos of the pieces with the domes and after their removal, showing the difference obtained with the latex coating: Group 1 (A,B), Group 2 (C,D), Group 3 (E,F) and Group $4(\mathbf{G}, \mathbf{H})$.

The specimens from Groups 3 and 4 presented soft tissue surrounding the domes but that did not penetrate it due to the presence of latex as a barrier. Figure $4 \mathrm{E}, \mathrm{G}$ show the samples of Group 3 , in which the domes were not covered by the periosteum, and Group 4, with periosteum coverage. The latex membrane takes on a whitish and opaque appearance when wet. These domes were easily removed after detachment from the implanted site. Figure $4 \mathrm{~F}, \mathrm{H}$ show the photos of the tissues inside the dome, very different from those in Groups 1 and 2, in which there was no latex coverage. The bone tissue formation inside them was observed.

\subsection{Computed Tomography Images}

Figure 5 shows tomographic slices and the 3-D reconstructed image of samples from Groups 3 and 4 . The vertical bone augmentation can be observed in the images. 


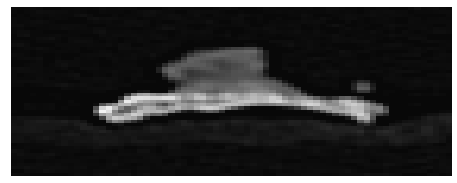

(A)

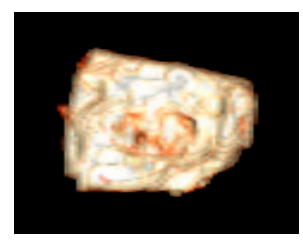

(C)

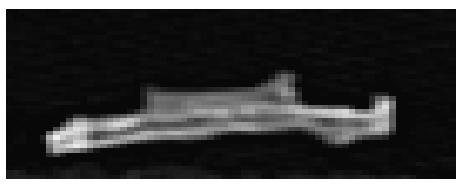

(B)

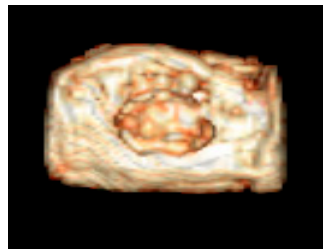

(D)

Figure 5. Tomographic images of Groups $3($ A,C) and 4 (B,D), where bone tissue beyond the skullcap can be observed.

\subsection{Microscopic Analysis}

Figure 6 shows the photomicrography of all the groups for comparison. In these images, the preexisting bone structure of the skullcap (SC) and the structure that was formed inside the dome can be seen. In Groups 3 and 4 (Figure 6C,D), in which the titanium mesh was covered with the latex layer, we verified bone tissue (BT) in the region of the dome, which grew above the skullcap. In Groups 1 and 2 (Figure 6A,B), we verified, predominantly, connective tissue (CT).

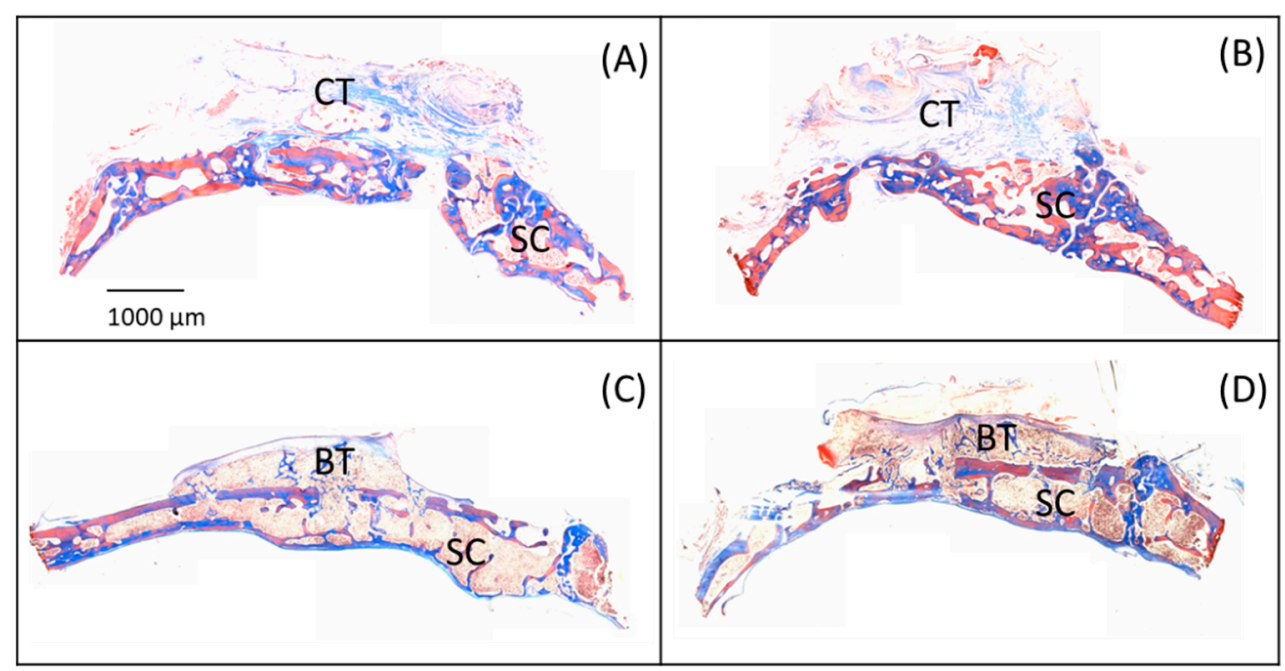

Figure 6. Photomicrographs of bone samples in the surgical site: (A) Group 1, (B) Group 2, (C) Group 3 and (D) Group 4. Groups 3 and 4 present bone tissue (BT) inside the dome region, above the skullcap (SC).

In the samples from Group 1 (control), islands of adipose tissue-surrounded and supported by fibrous connective tissue (Figure 7A, black arrow), characterized by tissue bundles occupying the dome space-were observed in the spaces delimited by the domes. The fibrous connective tissue has capsular organization and is continuous in the superior region of the domes (Figure 7B, green arrow). No inflammatory infiltrate was present; just a few diffuse leukocytes were so, randomly distributed in the space (Figure 7B). 


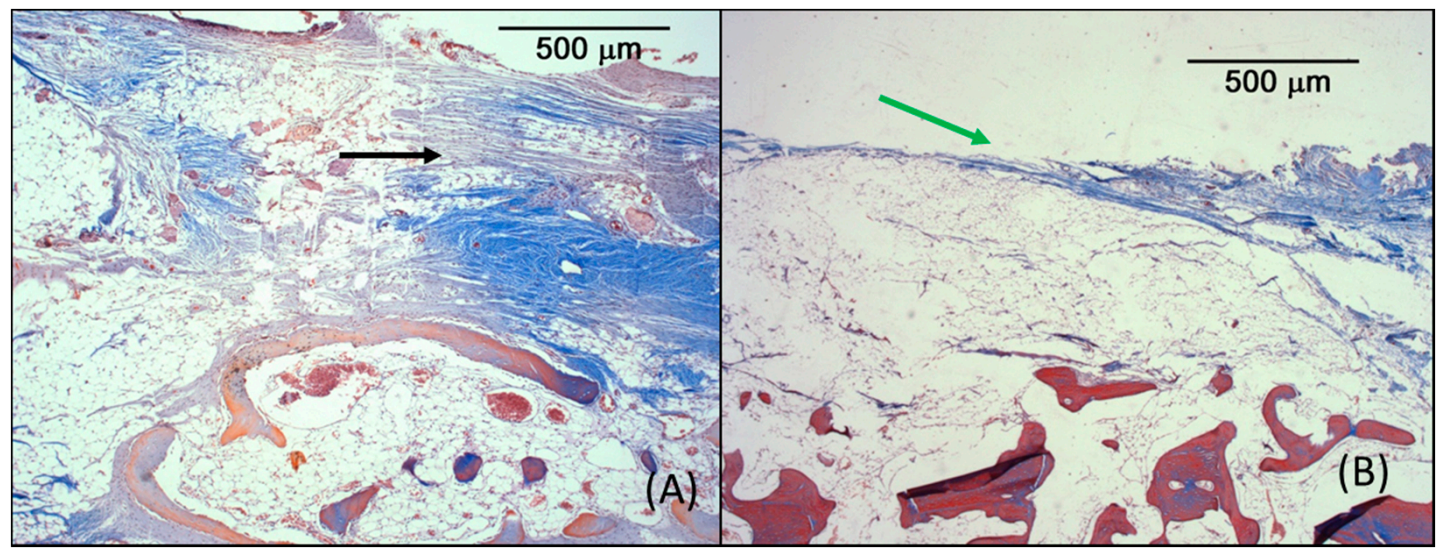

Figure 7. Microscopic images from Group 1 (control): (A) Connective tissue around adipose islands (black arrow). (B) Capsular connective tissue (green arrow).

In the samples from Group 2, the spaces surrounded by domes were also filled by adipose and fibrous tissue, with organization similar to that in the control group. The region formed by the connective tissue presented areas of fibrous tissue with collagen bundles with clusters of adipocytes. There were no signs of inflammatory infiltrate. The tissue is organized as a fibrous capsule at the periphery of formed tissue. (Figure 8A). In some samples (three of them), the presence of bone tissue was observed (Figure 8B). The newly formed bone tissue presented well-formed bone trabeculae and large marrow spaces filled with hematopoietically active bone marrow permeated by adipocytes. This bone tissue remained with the underlying bone, without any demarcation.

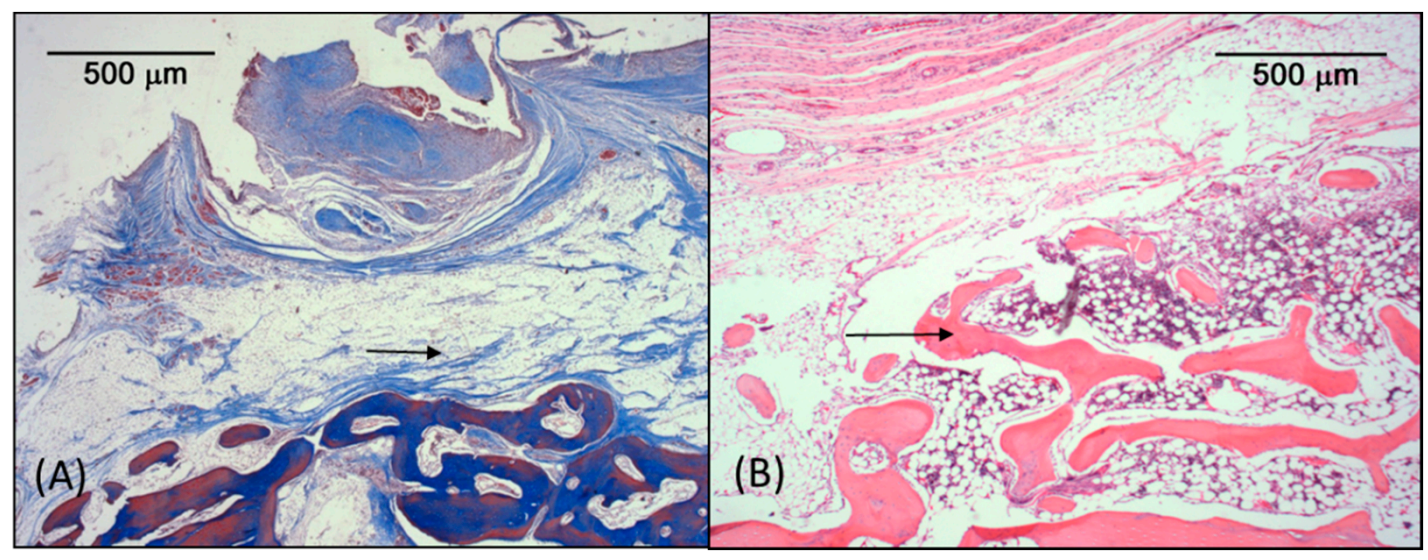

Figure 8. Microscopic images from Group 3: (A) Connective tissue around adipose islands (black arrow).

(B) Bone tissue present in some samples.

The space surrounded by the dome specimens from group 3 was completely filled with mature bone tissue with well-defined bone trabeculae and marrow spaces filled by active hematopoietic tissue and adipocytes (Figure 9A). The newly formed bone tissue reached the limits of the dome, merging into this periphery with capsular connective tissue (Figure 9B). There was no inflammatory infiltrate. 


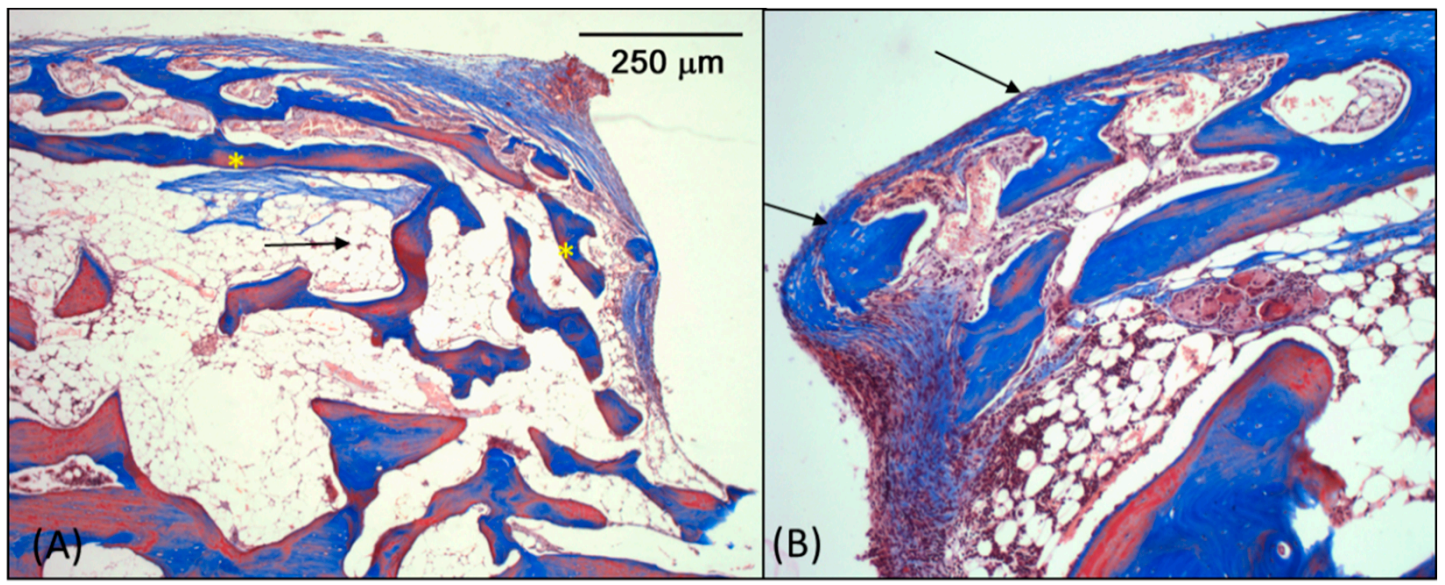

Figure 9. Microscopic images from Group 3: (A) Mature bone tissue $\left(^{*}\right)$ with well-defined bone trabeculae and marrow spaces (black arrow) filled by active hematopoietic tissue. (B) Newly formed bone reaching the limits of the dome.

The same structures of Group 3 were observed in the samples from Group 4 (Figure 10A), but, in this group, the space surrounded by the dome was filled by more delicate and more sparsely distributed lamellar bone tissue (Figure 10B) than that in Group 3, in which the periosteum was not placed over the domes.

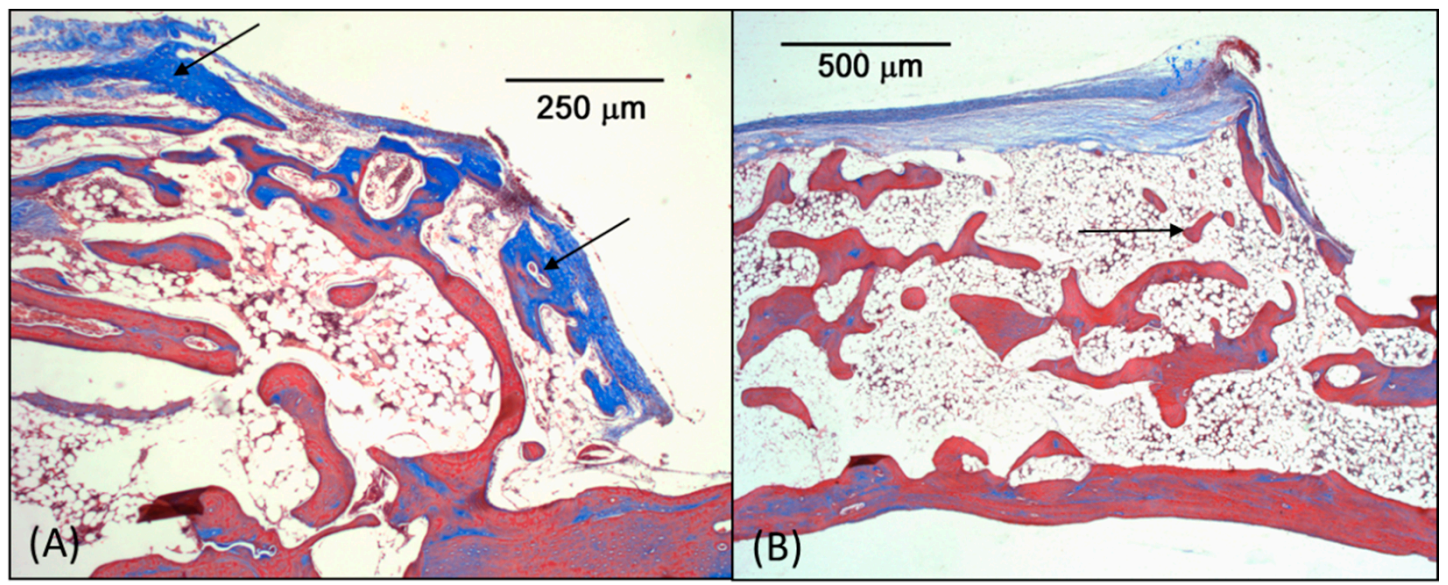

Figure 10. Microscopic images from Group 4: (A) Newly formed bone reaching the limits of the dome (black arrows). (B) Lamellar bone tissue dispersed within the dome.

Histomorphometric analyses were performed by measuring the area of the newly formed bone inside the dome region. The results were converted into percentages (in relation to the total area) and are presented in Figure 11 as means \pm SDs. The ANOVA (Origin version 8.5, OriginLab Corporation One, Northampton, MA, USA) followed by Tukey's test was used for comparison between the groups. There were no statistically significant differences between Groups 1 and 2, or between Groups 3 and 4 . The other comparisons showed significant differences $(p<0.05)$. The results are shown in Figure 11. 


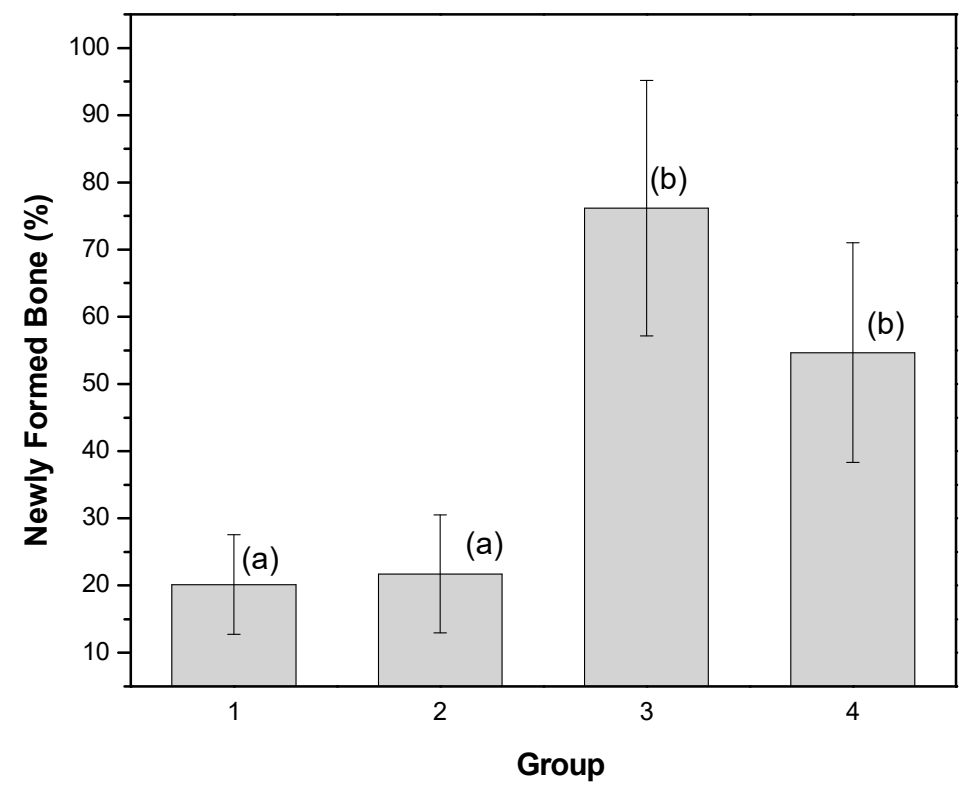

Figure 11. Percentage of newly formed bone (mineralized bone and marrow spaces) present inside the dome region. Different letters represent statistically significant differences ( $p<0.05$, ANOVA-Tukey).

\section{Discussion}

Tooth loss or extraction leads, over time, to the reduction of alveolar bone, which makes rehabilitation with implant placement difficult. Thus, guided bone regeneration (GBR) with a local increase in bone volume has contributed to the solution of this problem. Usually, this procedure is done with a combination of graft materials: bone grafting particles, a block bone graft, a cortical bone block [28] and allogeneic bone blocks [29] are often used, in association with an occlusive membrane, absorbable or not. Due to the wide variety of and heterogeneity among treatments, there is no conclusive proposal regarding the best treatment [28].

In this study, guided bone augmentation was promoted by a new biomaterial developed using a support structure of a titanium mesh molded into a dome shape and coated by natural latex from the Hevea brasiliensis tree. The biocompatibility of latex is described in the literature $[11,30,31]$. The titanium mesh is usually used for maxillofacial reconstruction procedures, when the stability of the bone to be formed does not come from the remaining bone walls of the defect, with advantages such as biocompatibility and rigidity but plasticity for molding. In some procedures, when associated with autologous bone, it promotes bone volume augmentation, allowing the placement of dental implants [32]. The coating with latex conferred occlusion capability to the mesh, since the pores of latex are smaller than $50 \mathrm{~nm}$ [13], with the advantage of the biological properties of latex. These properties can reduce the possibility of wound dehiscence, which is a relevant clinical point.

The domes used in this work had an internal volume average of $135 \mathrm{~mm}^{3}$, similar to the volumes described in the literature [33,34], differing from those in the studies of [35], which had a volume of only $33 \mathrm{~mm}^{3}$. The bone formation was also induced by marrow penetration, as described by Min et al. [23].

The results of the macroscopic examination of both Groups 1 and 2, in which the titanium mesh was not coated with latex, do not reveal bony formation. There was soft tissue surrounding the domes, linked to its internal area, in agreement with Yamada et al. [33], who reported the inflow of fibrous tissues through the holes in the hemispherical titanium capsule used in their study. However, the macroscopic appearance at 90 days post-surgery in Groups 3 and 4, in which the latex coating was used, showed soft tissue surrounding the domes but not penetrating into it, due to a physical barrier provided by the latex membrane. 
Microscopically, the absence of any barrier between the soft tissues and skull probably explains the filling with fibrous connective tissue and adipose tissue in Groups 1 and 2, since the connective tissue cells proliferate faster than cells with osteogenic potential [3]. The comparison of the results between these groups also showed that the periosteum did not influence the amount of bone tissue formed, as there is no statistical difference.

On the other hand, the comparison with the results of Groups 3 and 4 shows a higher amount of newly formed bone (Figure 11), demonstrating the performance of the barrier generated by the coating by natural latex. Previous studies have shown the ability of the natural latex membrane to act as an occlusive membrane in guided bone regeneration. Ereno et al. [13] demonstrated this capacity in critical size defects in the skull cap of rabbits. Moura et al. [14] showed that the latex membrane has advantages over the polytetrafluorethylene (PTFE) membrane, which is widely used, inducing bone repair more effectively. More recently, Marques et al. [21] showed this same function when latex is associated with silver nanoparticles. Areas of necrosis or inflammation were not noted in any of the specimens. The inflammatory infiltrates, when present, are in focal areas, made up of mononuclear or polymorphonuclear leukocytes, randomly dispersed, and probably from the remaining cells of the acute phase of inflammation in the post-surgical period. In all the experimental groups, the absence of multinucleated giant cells at the dome interface was noted, corroborating the results of Ereno et al. [13], who obtained similar results for latex film implantation.

The statistical analysis of the quantitative results for newly formed bone reveals no significant differences between Groups 3 and 4. However, the organization is different. In Group 3, the space surrounded by the dome was completely filled with trabecular bone tissue with well-defined and narrow spaces filled by active hematopoietic tissue and adipocytes (Figure 9A,B). In Group 4, the space surrounded by the dome proved to be filled by lamellar bone tissue that was more delicate and more sparsely distributed (Figure 10B). Unlike the results obtained in this work, Yamada et al. [33] observed, inside titanium domes, and Miyamoto et al. [36], inside titanium and poly (1-lactic acid) PLLA domes, bone tissue with thin trabeculae and large marrow tissue. Furthermore, no formation of cortical bone near the wall of the titanium was reported.

Therefore, we can conclude that the titanium mesh coated with natural latex is a promising biomaterial for guided bone augmentation procedures.

\section{Patents}

Produto e processo para recobrimento de malha de Titânio com Látex. Patents Application No. BR1020130205630 INPI-Brazil, 26 August 2014.

Author Contributions: Conceptualization, D.K.P., R.G.E., L.A.H., O.B., and A.K.; Validation, D.K.P., R.G.E., F.F.G.P., L.A.H., L.M., A.C., and A.K.; Formal Analysis, A.K., A.C., and O.B.; Investigation, D.K.P., R.G.E., F.F.G.P., L.A.H., L.M., A.C., C.F.O.G., O.B., and A.K.; Resources, A.K., C.F.O.G., and O.B.; Data Curation, A.K.; Writing-Original Draft Preparation, D.K.P., R.G.E., F.F.G.P., L.A.H., L.M., A.C., C.F.O.G., O.B., and A.K.; Writing-Review and Editing, D.K.P., R.G.E., F.F.G.P., and A.K.; Visualization, D.K.P., R.G.E., F.F.G.P., A.C., and A.K.; Supervision, A.K.; Project Administration, A.K.; Funding Acquisition, A.K., C.F.O.G., and O.B. All authors have read and agreed to the published version of the manuscript.

Funding: This research was partially funded by Brazilian agencies Fundação de Amparo à Pesquisa do Estado de São Paulo, grant number [FAPESP 03/09505-6, 13/07296-2 and 13/07699-0]; Coordenação de Aperfeiçoamento de Pessoal de Nível Superior, grant number [CAPES, Finance Code 001]; and Conselho Nacional de Desenvolvimento Científico e Tecnológico, grant number [CNPq code 304107/2019-0].

Acknowledgments: Wilson Orcini, Maira Rondina, Carlos Alberto Brunello, and Lourenço Rocha for technical assistance, and Elizabeth S. R. Somessari from Centro de Tecnologia das Radiações-CTRD IPEN for sample irradiation.

Conflicts of Interest: The authors declare no conflict of interest. 


\section{References}

1. Avila-Ortiz, G.; Bartold, M.; Giannobile, W.; Katagiri, W.; Nares, S.; Rios, H.; Spagnoli, D.; Wikesjö, U.M.E. Biologics and cell therapy tissue engineering approaches for the management of the edentulous maxilla: A systematic review. Int. J. Oral Maxillofac. Implant. 2016, 31, s121-s164. [CrossRef]

2. McAllister, B.S.; Haghighat, K. Bone augmentation techniques. J. Periodontol. 2007, 78, 377-396. [CrossRef] [PubMed]

3. Buser, D. Guided Bone Regeneration in Implant Dentistry, 2nd ed.; Quintessence: Chicago, IL, USA, 2009; ISBN 0867152494.

4. Roccuzzo, M.; Savoini, M.; Dalmasso, P.; Ramieri, G. Long-term outcomes of implants placed after vertical alveolar ridge augmentation in partially edentulous patients: A 10-year prospective clinical study. Clin. Oral Implant. Res. 2017, 28, 1204-1210. [CrossRef] [PubMed]

5. Zhang, P.; Ding, L.; Kasugai, S. Effect of doxycycline doped bone substitute on vertical bone augmentation on rat calvaria. Dent. Mater. J. 2019, 38, 211-217. [CrossRef] [PubMed]

6. Misch, C.M.; Jensen, O.T.; Pikos, M.A.; Malmquist, J.P. Vertical bone augmentation using recombinant bone morphogenetic protein, mineralized bone allograft, and titanium mesh: A retrospective cone beam computed tomography study. Int. J. Oral Maxillofac. Implant. 2015, 30, 202-207. [CrossRef]

7. Carrera-Arrabal, T.; Calvo-Guirado, J.L.; Passador-Santos, F.; Sorgi da Costa, C.E.; Teles Costa, F.R.; Aloise, A.C.; Napimoga, M.H.; Aragoneses, J.M.; Pelegrine, A.A. Vertical bone construction with bone marrow-derived and adipose tissue-derived stem cells. Symmetry 2019, 11, 59. [CrossRef]

8. Dupoirieux, L.; Pourquier, D.; Picot, M.; Neves, M. Comparative study of three different membranes for guided bone regeneration of rat cranial defects. Int. J. Oral Maxillofac. Surg. 2001, 30, 58-62. [CrossRef]

9. Bottino, M.C.; Thomas, V.; Schmidt, G.; Vohra, Y.K.; Chu, T.G.; Kowolik, M.J.; Janowski, G.M.; Lafayette, W. Recent advances in the development of GTR/GBR membranes for periodontal regeneration-A materials perspective. Dent. Mater. 2012, 28, 703-721. [CrossRef]

10. Wöltje, M.; Brünler, R.; Böbel, M.; Ernst, S.; Neuss, S.; Aibibu, D.; Cherif, C. Functionalization of silk fibers by PDGF and bioceramics for bone tissue regeneration. Coatings 2020, 10, 8. [CrossRef]

11. Mendonça, R.J.; Maurício, V.B.; Teixeira, L.d.B.; Lachat, J.J.; Coutinho-Netto, J. Increased vascular permeability, angiogenesis and wound healing induced by the serum of natural latex of the rubber tree Hevea brasiliensis. Phytother. Res. 2010, 24, 8-764. [CrossRef]

12. Kerche-silva, L.E.; Gomes, D.; Morais, S.; Danna, C.S.; Gomes, A.S.; Moratto, I.; Cecchini, A.L.; Yoshihara, E.; Job, A.E. Free-radical Scavenging properties and cytotoxic activity evaluation of latex C-serum from hevea brasiliensis RRIM 600. Free Radic. Antioxid. 2017, 7, 107-114. [CrossRef]

13. Ereno, C.; Guimarães, S.A.C.; Pasetto, S.; Herculano, R.D.; Silva, C.P.; Graeff, C.F.O.; Tavano, O.; Baffa, O.; Kinoshita, A. Latex use as an occlusive membrane for guided bone regeneration. J. Biomed. Mater. Res. Part A 2010, 95A, 932-939. [CrossRef] [PubMed]

14. Moura, J.M.L.; Ferreira, J.F.; Marques, L.; Holgado, L.; Graeff, C.F.O.; Kinoshita, A. Comparison of the performance of natural latex membranes prepared with different procedures and PTFE membrane in guided bone regeneration (GBR) in rabbits. J. Mater. Sci. Mater. Med. 2014, 25, 2111-2120. [CrossRef] [PubMed]

15. Herculano, R.D.; Silva, C.P.; Ereno, C.; Guimaraes, S.A.C.; Kinoshita, A.; Graeff, C.F.d.O. Natural rubber latex used as drug delivery system in guided bone regeneration (GBR). Mater. Res. 2009, 12, 253-256. [CrossRef]

16. Herculano, R.D.; Alencar de Queiroz, A.A.; Kinoshita, A.; Oliveira, O.N.; Graeff, C.F.O. On the release of metronidazole from natural rubber latex membranes. Mater. Sci. Eng. C 2011, 31, 272-275. [CrossRef]

17. Herculano, R.D.; Guimarães, S.A.C.; Belmonte, G.C.; Duarte, M.A.H.; de Oliveira, O.N.; Kinoshita, A.; Graeff, C.F.d.O. Metronidazole release using natural rubber latex as matrix. Mater. Res. 2010, 13, 57-61. [CrossRef]

18. de Barros, N.R.; Miranda, M.C.R.; Borges, F.A.; Gemeinder, J.L.P.; de Mendonça, R.J.; Cilli, E.M.; Herculano, R.D. Natural rubber latex: Development and in vitro characterization of a future transdermal patch for enuresis treatment. Int. J. Polym. Mater. Polym. Biomater. 2017, 66, 871-876. [CrossRef]

19. Almeida, G.F.B.; Cardoso, M.R.; Zancanela, D.C.; Bernardes, L.L.; Norberto, A.M.Q.; Barros, N.R.; Paulino, C.G.; Chagas, A.L.D.; Herculano, R.D.; Mendonça, C.R. Controlled drug delivery system by fs-laser micromachined biocompatible rubber latex membranes. Appl. Surf. Sci. 2020, 506, 144762. [CrossRef] 
20. Guidelli, É.J.; Kinoshita, A.; Ramos, A.P.; Baffa, O.; Guidelli, E.J.; Kinoshita, A.; Ramos, A.P.; Baffa, O. Silver nanoparticles delivery system based on natural rubber latex membranes. J. Nanoparticle Res. 2013, 15, 1-9. [CrossRef]

21. Marques, L.; Martinez, G.; Guidelli, É.; Tamashiro, J.; Segato, R.; Payão, S.L.M.; Baffa, O.; Kinoshita, A. Performance on bone regeneration of a silver nanoparticle delivery system based on natural rubber membrane NRL-AgNP. Coatings 2020, 10, 323. [CrossRef]

22. Tamura, T.; Fukase, Y.; Goke, E.; Yamada, Y.; Sato, S.; Nishiyama, M.; Ito, K. Three-dimensional evaluation for augmented bone using guided bone regeneration. J. Periodontal Res. 2005, 40, 269-276. [CrossRef]

23. Min, S.; Sato, S.; Murai, M.; Okuno, K.; Fujisaki, Y.; Yamada, Y.; Ito, K. Effects of marrow penetration on bone augmentation within a titanium cap in rabbit calvarium. J. Periodontol. 2007, 78, 1978-1984. [CrossRef] [PubMed]

24. Min, S.; Sato, S.; Saito, M.; Ebihara, H.; Arai, Y.; Ito, K. Micro-computerized tomography analysis: Dynamics of bone augmentation within a titanium cap in rabbit calvarium. Oral Surg. Oral Med. Oral Pathol. Oral Radiol. Endodontol. 2008, 106, 892-895. [CrossRef] [PubMed]

25. Sanz, M.; Vignoletti, F. Key aspects on the use of bone substitutes for bone regeneration of edentulous ridges. Dent. Mater. 2015, 31, 640-647. [CrossRef] [PubMed]

26. Arrington, E.D.; Smith, W.J.; Chambers, H.G.; Bucknell, A.L.; Davino, N.A. Complications of iliac crest bone graft harvesting. Clin. Orthop. Relat. Res. 1996, 329, 300-309. [CrossRef] [PubMed]

27. Institute of Laboratory Animal Resources. Guide for the Care and Use of Laboratory Animals; The National Academies Press: Washington, DC, USA, 1985; Volume 23-86.

28. Khojasteh, A.; Kheiri, L.; Motamedian, S.R.; Khoshkam, V. Guided bone regeneration for the reconstruction of alveolar bone defects. Ann. Maxillofac. Surg. 2017, 7, 263. [CrossRef] [PubMed]

29. Moest, T.; Frabschka, J.; Kesting, M.R.; Schmitt, C.M.; Frohwitter, G.; Lutz, R.; Schlegel, K.A. Osseous ingrowth in allogeneic bone blocks applied for vertical bone augmentation: A preclinical randomised controlled study. Clin. Oral Investig. 2019, 1-13. [CrossRef]

30. Balabanian, C.A.C.A.; Coutinho-Netto, J.; Lamano-Carvalho, T.L.; Lacerda, S.A.; Brentegani, L.G. Biocompatibility of natural latex implanted into dental alveolus of rats. J. Oral Sci. 2006, 48, 201-205. [CrossRef]

31. Floriano, J.; Mota, L.; Furtado, E.; Rossetto, V.; Graeff, C.O. Biocompatibility studies of natural rubber latex from different tree clones and collection methods. J. Mater. Sci. Mater. Med. 2014, 25, 461-470. [CrossRef]

32. Louis, P.J. Vertical ridge augmentation using titanium mesh. Oral Maxillofac. Surg. Clin. 2010, 22, 353-368. [CrossRef]

33. Yamada, Y.; Nanba, K.; Ito, K. Effects of occlusiveness of a titanium cap on bone generation beyond the skeletal envelope in the rabbit calvarium. Clin. Oral Implant. Res. 2003, 14, 455-463. [CrossRef] [PubMed]

34. Lundgren, A.K.; Lundgren, D.; Hämmerle, C.H.; Nyman, S.; Sennerby, L. Influence of decortication of the donor bone on guided bone augmentation. An experimental study in the rabbit skull bone. Clin. Oral Implant. Res. 2000, 11, 99-106. [CrossRef]

35. Lundgren, D.; Slotte, C.; Lundgren, D.; Sennerby, L. Bone morphology and vascularization of untreated and guided bone augmentation-treated rabbit calvaria: Evaluation of an augmentation model. Clin. Oral Implant. Res. 2005, 16, 228-235. [CrossRef]

36. Miyamoto, I.; Tsuboi, Y.; Takahashi, K.; Hyon, S.-H.; Iizuka, T. Enhancement of bone volume in guided bone augmentation by cell transplants derived from periosteum: An experimental study in rabbit calvarium bone. Clin. Oral Implant. Res. 2004, 15, 308-314. [CrossRef] [PubMed]

(C) 2020 by the authors. Licensee MDPI, Basel, Switzerland. This article is an open access article distributed under the terms and conditions of the Creative Commons Attribution (CC BY) license (http://creativecommons.org/licenses/by/4.0/). 